\title{
The application of flow cytometry in determining the bacteriological quality of raw sheep's milk in Slovakia
}

\author{
Martin TOMÁŠKKA ${ }^{a *}$, Gertraud SUHREN ${ }^{b}$, Oto HANUŠc ${ }^{c}$ Hans-Georg WALTE ${ }^{b}$, \\ Anna SLOTTOVÁa ${ }^{a}$ Margita HOFERICOVÁa \\ a TL Examinala, Výskumný ústav mliekárenský, a.s., Dlhá 95, 01001 Žilina, Slovakia \\ $\mathrm{b}$ Federal Research Centre for Nutrition and Food - location Kiel, Hermann-Weigmann-Strasse 1, \\ 24103 Kiel, Germany \\ c Výzkumný ústav chovu skotu, s.r.o., Rapotín 267, 78813 Vikýřovice, Czech Republic
}

Received 25 February 2005 - Accepted 11 October 2005

\begin{abstract}
In this study enumeration of bacterial cells in raw sheep's bulk milk by an automated flow cytometry method (Bactoscan FC) was evaluated. The results were discussed with respect to the results obtained by the analysis of cow's milk. Within-laboratory reproducibility, which depended on the counting level, was slightly worse than that of raw cow's milk (valued in the interval $>50$ Individual Bacterial Cell $\left.(\mathrm{IBC}) \cdot \mu \mathrm{L}^{-1}\right)$. In routine procedure, if preceding samples had counts $>20000 \mathrm{IBC} \cdot \mu \mathrm{L}^{-1}$, then this was observed to increase the count of the following sample significantly in many cases ("carry-over"). Bactoscan counts were moderately enhanced with increasing numbers of somatic cells in sheep's milk. However, this trend was indicated only in samples with lower plate counts $\left(<10^{5}\right.$ colony-forming units $\left.(\mathrm{CFU}) \cdot \mathrm{mL}^{-1}\right)$. The regression equation between the results of the anchor plate method and the Bactoscan method was computed from the sample set which represented sheep's milk production in Slovakia during 2004 (data between percentiles 1 and 99, $n=877): \log _{10} \mathrm{CFU} \cdot \mathrm{mL}^{-1}=1.088 \log _{10} \mathrm{IBC} \cdot \mu \mathrm{L}^{-1}+2.292$; with an accuracy of the estimate, expressed as standard deviation of regression $\mathrm{s}_{\mathrm{y}, \mathrm{x}}=0.305 \log _{10} \mathrm{CFU} \cdot \mathrm{mL}^{-1}$. The actual regression for raw cow's milk was verified, introducing both raw cow's milk samples and raw sheep's milk samples. The transformation of IBC $\cdot \mu \mathrm{L}^{-1}$ to CFU. $\mathrm{mL}^{-1}$ realised by various published conversions was evaluated by testing of the parallelism of the regression lines and also by comparison of obtained differences on a model data set. The conclusions support the requirement to set up a special conversion for the intended field of application at any time.
\end{abstract}

bacteriological quality / raw sheep's milk / flow cytometry / somatic cells

摘要 - 应用流式细胞术检测斯洛伐克绵羊奶原料奶的细菌数量。本研究应用自动流式细胞 计数仪 (Bactoscan FC) 对大量绵羊奶原料奶样品的细菌数量进行检测, 并对该检测方法的适 用性进行了评价。在两个实验室内采用同样的分析方法进行对比分析, 其中一个实验室同 时检测牛奶原料奶和绵羊奶原料的细菌数量, 另一个实验室只检测牛奶原料奶的细菌数 量, 并对检测结果进行了分析和讨论。试验结果表明在同一试验室内测定结果的重现性取 决于样品中单细菌细胞数量 (IBC $\left.\cdot \mu \mathrm{L}^{-1}\right)$, 当样品中单细菌细胞数量 $>50 \mathrm{IBC} \cdot \mu \mathrm{L}^{-1}$ 时, 绵羊奶 测定结果的重现性稍差于牛奶的测定结果。当样品中单细菌细胞数量 $>20000 \mathrm{IBC} \cdot \mu \mathrm{L}^{-1}$ 时, 会使下一个样品的测定结果偏高。另外随着绵羊奶样品中体细胞数量的增加, 会影响流式

* Corresponding author (通讯作者): tomaska@vumza.sk 
细胞法计数结果的准确性, 但是, 只有在样品的菌数较低的情况下 (用平板计数法测定菌数 $\left.<10^{5} \mathrm{CFU} \cdot \mathrm{mL}^{-1}\right)$ 才会出现这种趋势。按照常规的程序操作, 如果之前测定样品的细菌细胞 数大于 $20000 \mathrm{IBC} \cdot \mu \mathrm{L}^{-1}$, 那么通常在其后测定的样品的细菌细胞数会明显增加（ “残留效 应”)。对 2004 年斯洛伐克生产的一批绵羊奶样品分别采用平板计数法和流式细胞计数法 进行检测, 建立了两种计数方法之间的回归方程为 (利用的数据在 1-99 百分数之间, $n=877$ ): $\log _{10} \mathrm{CFU} \cdot \mathrm{mL}^{-1}=1.088 \log _{10} \mathrm{IBC} \cdot \mu \mathrm{L}^{-1}+2.292$; 回归方程的标准偏差 $\mathrm{s}_{\mathrm{y}, \mathrm{x}}=$ $0.305 \log _{10} \mathrm{CFU} \cdot \mathrm{mL}^{-1}$ 。根据牛奶测定结果建立的由 $\mathrm{IBC} \cdot \mu \mathrm{L}^{-1}$ 转换成 $\mathrm{CFU} \cdot \mathrm{mL}^{-1}$ 的线性回归 方程, 经牛奶和绵羊奶测定结果验证后方程是有效的。选择一些文献报道的由 IBC. $\mu \mathrm{L}^{-1}$ 转 换成 CFU.mL -1 的线性回归方程, 将测定结果带入方程进行了回归分析。研究结果表明流 式细胞计数法应用于不同的对象都需要建立一套与之相适应的计数转换方程以满足不同分 析对象的要求。

细菌学质量 / 绵羊奶原料奶 / 流式细胞计数 / 体细胞

Résumé - L'application de la cytométrie de flux pour déterminer la qualité bactériologique du lait cru de brebis en Slovaquie. Dans cette étude, la numération des cellules bactériennes a été évaluée dans le lait cru de brebis de grand mélange par la cytométrie de flux automatisée (Bactoscan FC). Les résultats ont été comparés à ceux obtenus sur le lait de vache. La reproductibilité interne au laboratoire augmentait avec le niveau de la numération et était légèrement inférieure à celle obtenue sur lait cru de vache (pour les valeurs $>50$ cellules bactériennes individuelles $\left.(\mathrm{CBI}) \cdot \mu \mathrm{L}^{-1}\right)$. $\mathrm{La}$ méthode de routine a montré que si les échantillons précédents avaient un niveau de contamination $>20000 \mathrm{CBI} \cdot \mu \mathrm{L}^{-1}$, cela pouvait fréquemment augmenter significativement les valeurs dénombrées dans l'échantillon suivant ("carry over"). L'augmentation des cellules somatiques dans le lait de brebis entraînait une légère augmentation des valeurs de dénombrements par Bactoscan. Cependant cette tendance n'a été observée que dans les échantillons ayant les plus faibles niveaux de dénombrements sur boîte $\left(<10^{5}\right.$ unités formant des colonies (UFC) $\left.\mathrm{mL}^{-1}\right)$. L'équation de régression entre les résultats de dénombrements sur boîte et de dénombrements par Bactoscan a été calculée à partir de l'ensemble des échantillons représentant la production du lait de brebis en Slovaquie pendant l'année 2004 (données entre les centiles 1 et $99, n=877$ ) : $\log _{10}$ UFC $\cdot \mathrm{mL}^{-1}=1,088 \log _{10} \mathrm{CBI} \cdot \mu \mathrm{L}^{-1}+$ 2,292 ; avec une précision de l'estimation, exprimée en écart-type de la régression $\mathrm{s}_{\mathrm{y}, \mathrm{x}}=$ $0,305 \log _{10} \mathrm{UFC} \cdot \mathrm{mL}^{-1}$. La régression réelle pour le lait de vache cru a été vérifiée en introduisant à la fois les échantillons du lait de vache cru et ceux du lait de brebis cru. La transformation du $\mathrm{CBI} \cdot \mu \mathrm{L}^{-1}$ en UCF.mL ${ }^{-1}$, réalisée par plusieurs conversions publiées, a été évaluée en testant le parallélisme des courbes de régression ainsi qu'en comparant les différences obtenues avec un ensemble de données modèle. En conclusion, il apparaît nécessaire d'établir une conversion spécifique pour chaque champ d'application envisagé.

qualité bactériologique / lait cru de brebis / cytométrie de flux / cellule somatique

\section{INTRODUCTION}

The measurement of single cells by flow cytometers started to develop in the first half of the 20th century. In milk analysis this methodology was first applied to somatic cell counting. The utilisation of flow cytometry in the field of bacterial counting was limited due to their small size and consequently the low concentrations of cellular constituents of microbial cells and disturbing matrix effects. Only improvements in light sources, in optics technology and better fluorescent staining of cells helped in successful application in microbiology [16].
The Bactoscan ${ }^{\circledR}$ (BSC-FC) developed by Foss Electric (Hillerød, Denmark) is an example of an automated flow cytometer for the counting of bacteria in raw milk. It is a proprietary technique. Briefly, in this instrument, milk components such as somatic cells, fat globules and proteins are first reduced/dispersed by chemical/heat treatment to prevent the influence of the matrix on counting. Next, bacteria are stained with a fluorescent dye, ordered to a mono-cell layer and then they pass a detector one by one. Light from a laser source excites the stained particles which emit light pulses that are detected and counted if 
they are higher than the fixed threshold. The results are primarily expressed in units designated as Individual Bacterial Cells (IBC) $\cdot \mu \mathrm{L}^{-1}$ [16]. For comparability they should be transformed into internationally accepted Colony-Forming Units (CFU) $\mathrm{mL}^{-1}$, in which results from the anchor/reference method [6] are expressed and limits for acceptance of milk [13] are given.

In general, the establishment of a suitable conversion is an essential element in the validation of a routine microbiology method [15]. It can be achieved by following international standards $[7,10]$. The application of this approach in BSC-FC methodology has been described in several works $[11,19$, 20]. Summarisation of calculated regressions was done by Suhren et al. [18]. Additionally, other aspects of the method have also been evaluated; for example, precision and accuracy [3, 11, 17], carry-over [4, 16], measuring range and linearity $[4,11,16]$ and effect of somatic cells on counting [3, $11,16]$.

However, in all the above-mentioned works only raw cow's milk was used as a model. Information about the possibility of measuring bacteriological quality of raw milk from other species by flow cytometry has been published only rarely [18]. Therefore, raw sheep's milk was examined here. Its biological, physical and chemical properties differ from raw cow's milk $[1,2]$.

The aim of the presented study is to:

- provide some describing criteria of the method;

- establish the conversion relationship between IBC and CFU results in raw sheep's bulk milk from Slovakia;

- verify whether it is necessary to apply different conversion equations for cow's and sheep's milk.

\section{MATERIALS AND METHODS}

\subsection{Samples}

For the purpose of the study bulk samples of raw sheep's milk and raw cow's milk were used. They were sampled in farms by qualified operators from dairies from April 2004 to September 2004, since sheep's milk is produced especially in this period. Sheep's milk was taken by hand only and cow's milk by hand as well as by automatic samplers in part. The structure of the samples represents the situation of milk production in Slovakia. Samples were immediately preserved with azidiol (Merck, Darmstadt, Germany) [12] - $0.15 \mathrm{~mL}$ per $45 \mathrm{~mL}$ of milk, and they were transported under cooling conditions $\left(\leq 10^{\circ} \mathrm{C}\right)$ to laboratories. Sheep's milk was analysed in TL Examinala, Žilina (laboratory I) and cow's milk also in TL Examinala, Žilina as well as in TL Milex-Progres, Bratislava (laboratory II). All samples damaged during transport or with a temperature $>10^{\circ} \mathrm{C}$ were excluded from further tests.

\subsection{Methods}

Sheep's milk was tested for inhibitors, bacteriological quality (by BSC-FC and the anchor method) and for somatic cell count (SCC) in this order. In cow's milk, only bacteriological quality was measured by BSC-FC and by the anchor method. Samples were analysed on the day after sampling (within $36 \mathrm{~h}$ ) and they were stored in refrigerators at $6{ }^{\circ} \mathrm{C} \pm 2{ }^{\circ} \mathrm{C}$ until analysis. The gaps between the performed tests were as short as possible; in the case of BC-FC and standard plate count (SPC) the maximal pause was $\leq 3 \mathrm{~h}$.

\subsubsection{Bacteriological quality}

To evaluate bacteriological quality, samples were measured in duplicate at ambient temperature by the routine method [14] on Bactoscan ${ }^{\circledR}$ FC 50 H (Foss Electric), first.

Subsequently, the anchor method - SPC was performed according to EN ISO 4833 [6]. Depending on IBC $\cdot \mu \mathrm{L}^{-1}$ two appropriate subsequent dilutions (between the 2nd and 6th) were examined. As the culture medium, Modified Skim Milk Agar (HiMedia Laboratories, Mumbai, India) was applied. Only Petri dishes containing more than 15 and fewer than 300 colonies were used for recording results. At least every 10th sample was analysed in duplicate. 


\subsubsection{Other tests}

Inhibitors were detected by the microbial inhibition method - Delvotest ${ }^{\circledR}$ SP (DSM Food Specialties, Delft, the Netherlands). Samples containing inhibitors were excluded from establishment of conversion and from verification studies.

Somatic cells were counted on a Fossomatic ${ }^{\circledR} 5000$ (Foss Electric) (FM).

The methods were performed according to internal standard operational procedure based on the manufacturer's recommendations.

\subsection{Quality control}

The involved laboratories were accredited to fulfil the criteria of EN ISO/IEC 17025 [5]. The field of accreditation covered all applied methods. Each analyst was trained to perform tests.

The performance within the laboratory was controlled by several tools. As advised by the manufacturer's procedure, during routine measurements carry-over of BSC$\mathrm{FC}$ and $\mathrm{FM}$ was checked on a regular basis with raw cow's milk and only values below $0.5 \%$ and $1.0 \%$, respectively, were accepted for compensation.

In establishment of conversion and in verification studies only the results from bacteriological quality were included:

- where standard deviation of repeatability $\left(\mathrm{s}_{\mathrm{r}}\right)$ met the requirements of the standards [6, 14]; and

- which were in the measuring range recommended by the manufacturer of BSCFC $\left(10 \mathrm{IBC} \cdot \mu \mathrm{L}^{-1}-20000 \mathrm{IBC} \cdot \mu \mathrm{L}^{-1}\right)$.

In order to control the counting level during the test period on each examination day, these reference samples were measured: Bacterial control samples (Foss Electric), Milk control standards (A. Hüfner, Wangen im Allgäu, Germany) and our own pilot samples by BSC-FC; Foss adjustment samples (frequency one sample per week) (Foss Electric), Reference samples (State Veterinary Institute, Prague, Czech Republic) and our own pilot samples by FM. Penicillin positive control, and Sulphonamide positive control and negative control (DSM
Food Specialties) were used to control testing by Delvotest ${ }^{\circledR}$ SP. A pre-requisite for the inclusion of analytical data in the evaluation was that the results of the control samples were within acceptable limits.

The laboratories participated regularly in interlaboratory tests. They were organised by A. Hüfner; Milcom-VÚM, the Czech Republic and the State Veterinary Institute, Prague, and were focused on evaluation of bacteria and somatic cell counting by all the methods involved here.

\subsection{Calculations and statistical analysis}

The results from bacteriological quality in IBC $\cdot \mu \mathrm{L}^{-1}$ and $\mathrm{CFU} \cdot \mathrm{mL}^{-1}$ were transformed before evaluation into $\log _{10}$ form.

The standard deviation of repeatability and standard deviation of within-laboratory reproducibility $\left(s_{R 1}\right)$ were determined in accordance with [9] whereby samples were measured in duplicate. For calculations of $\mathrm{s}_{\mathrm{R} 1}$, measurements from the same laboratory obtained from the same instrument but by different operators on different days were used.

The correlation coefficient $\left(R_{\mathrm{x}, \mathrm{y}}\right)$ and standard deviation of regression $\left(\mathrm{s}_{\mathrm{y}, \mathrm{x}}\right)$ were calculated in agreement with [9].

Data were analysed by statistical tests published elsewhere (pair $t$-test, $t$-test for significance of $R_{\mathrm{x}, \mathrm{y}}$ ).

Parallelism of regression lines was judged according to the significance of differences between regression coefficients $[9,10]$.

As computing software, Microsoft Excel $^{\circledR} 2002$ (Microsoft, USA) or System 4000 (Foss Electric) were used.

\section{RESULTS}

\subsection{Method describing criteria}

\subsubsection{Within-laboratory reproducibility}

The standard deviation of within-laboratory reproducibility of BSC-FC counts, fitting in IBC intervals, is summarised in 
Table I. Within-laboratory reproducibility depending on level of Bactoscan counts (IBC $\mu \mathrm{L}^{-1}$ ).

\begin{tabular}{|c|c|c|c|c|c|c|}
\hline \multirow{4}{*}{$\begin{array}{l}\text { Bactoscan } \\
\text { counts } \\
\left(\text { IBC } \cdot \mu L^{-1}\right)\end{array}$} & \multicolumn{4}{|c|}{ Laboratory I } & \multirow{2}{*}{\multicolumn{2}{|c|}{$\frac{\text { Laboratory II }}{\text { Raw cow's milk }}$}} \\
\hline & \multicolumn{2}{|c|}{ Raw sheep's milk } & \multicolumn{2}{|c|}{ Raw cow's milk } & & \\
\hline & $n$ & $\mathrm{~s}_{\mathrm{Rl}}$ & $n$ & $\mathrm{~s}_{\mathrm{Rl}}$ & $n$ & $\mathrm{~s}_{\mathrm{Rl}}$ \\
\hline & & $\left(\log _{10} \mathrm{IBC} \cdot \mu \mathrm{L}^{-1}\right)$ & & $\left(\log _{10} \mathrm{IBC} \cdot \mu \mathrm{L}^{-1}\right)$ & & $\left(\log _{10}\right.$ IBC $\left.\cdot \mu \mathrm{L}^{-1}\right)$ \\
\hline $10-50$ & 12 & 0.162 & 120 & 0.064 & 92 & 0.057 \\
\hline $51-200$ & 53 & 0.059 & 166 & 0.056 & 106 & 0.058 \\
\hline 201-2000 & 598 & 0.043 & 21 & 0.024 & 42 & 0.036 \\
\hline 2001-20000 & 274 & 0.025 & 8 & 0.007 & - & - \\
\hline$>20000$ & 92 & 0.007 & - & - & - & - \\
\hline
\end{tabular}

$n$ : number of samples; $\mathrm{s}_{\mathrm{R} I}$ : standard deviation of within-laboratory reproducibility.

Table I for raw sheep's milk (one laboratory) and raw cow's milk (two laboratories). It can be seen that $\mathrm{s}_{\mathrm{R}}$ for raw sheep's milk varied between $0.007 \log _{10} \mathrm{IBC} \cdot \mu \mathrm{L}^{-1}$ and $0.162 \log _{10} \mathrm{IBC} \cdot \mu \mathrm{L}^{-1}$.

\subsubsection{Effect of somatic cells on counting}

The results from bacteriological quality were grouped according to SCC. Within formed groups, the data were sorted in accordance with selected $\log _{10} \mathrm{CFU} \cdot \mathrm{mL}^{-1}$ intervals. Calculated geometric means and geometric relative standard deviations of BSC-FC counts are given in Table II.

\subsection{Conversion into CFU}

\subsubsection{Characterisation of the data set}

913 result pairs from bacteriological examination of raw sheep's milk by both the anchor method [6] (summarised in Tab. III) and BSC-FC fulfilled the required quality criteria for establishment of specific conversion and verification studies. These were used to create the basic data set. The geometric mean of colony counts was $x_{\mathrm{g}}=$ 358000 CFU.mL ${ }^{-1}$ with geometric relative standard deviation, GRSD $=386.5 \%$.

Simultaneously with these analyses, somatic cells were counted. Due to a brief technological problem with FM, it was not possible to measure 36 samples. The remaining results $(n=877)$ are characterised in
Table IV. The geometric mean was $x_{\mathrm{g}}=$ $636000 \mathrm{SCC} \cdot \mathrm{mL}^{-1}$ with GRSD $=61.8 \%$.

\subsubsection{Conversion for sheep's milk}

To establish the conversion of IBC into CFU for raw sheep's milk, the model of linear regression was chosen $[11,19,20]$. Values in $\log _{10} \mathrm{IBC} \cdot \mu \mathrm{L}^{-1}$ were set as the independent variable $-x$ and values from the anchor method in $\log _{10} \mathrm{CFU} \cdot \mathrm{mL}^{-1}$ were set as the dependent variable $-y$ [19]. The data set was reduced by $1 \%$ of the lowest and $1 \%$ of the highest values for both parameters $(n=877)$ in order to reach as far as possible a normal distribution of results and to limit the effect of extreme values on the position of the regression line [19, 20]. The final regression:

$\log _{10}$ CFU $\cdot \mathrm{mL}^{-1}=1.088 \log _{10} \mathrm{IBC} \cdot \mu \mathrm{L}^{-1}+$ 2.292; with an accuracy of the estimate of $\mathrm{s}_{\mathrm{y}, \mathrm{x}}=0.305 \log _{10} \mathrm{CFU} \cdot \mathrm{mL}^{-1}$ was computed (Fig. 1).

\subsubsection{Verification of the conversion for raw cow's milk}

In Slovakia, a rolling conversion system is used in the process of the verification of the raw cow's milk regression [10, 22]. Between April 2004 and September 2004 a new set of raw cow's milk samples was introduced $(n=525$, SPC between $3300 \mathrm{CFU} \cdot \mathrm{mL}^{-1}$ and $1100000 \mathrm{CFU} \cdot \mathrm{mL}^{-1}$ with geometric mean $35000 \mathrm{CFU} \cdot \mathrm{mL}^{-1}$ ). 


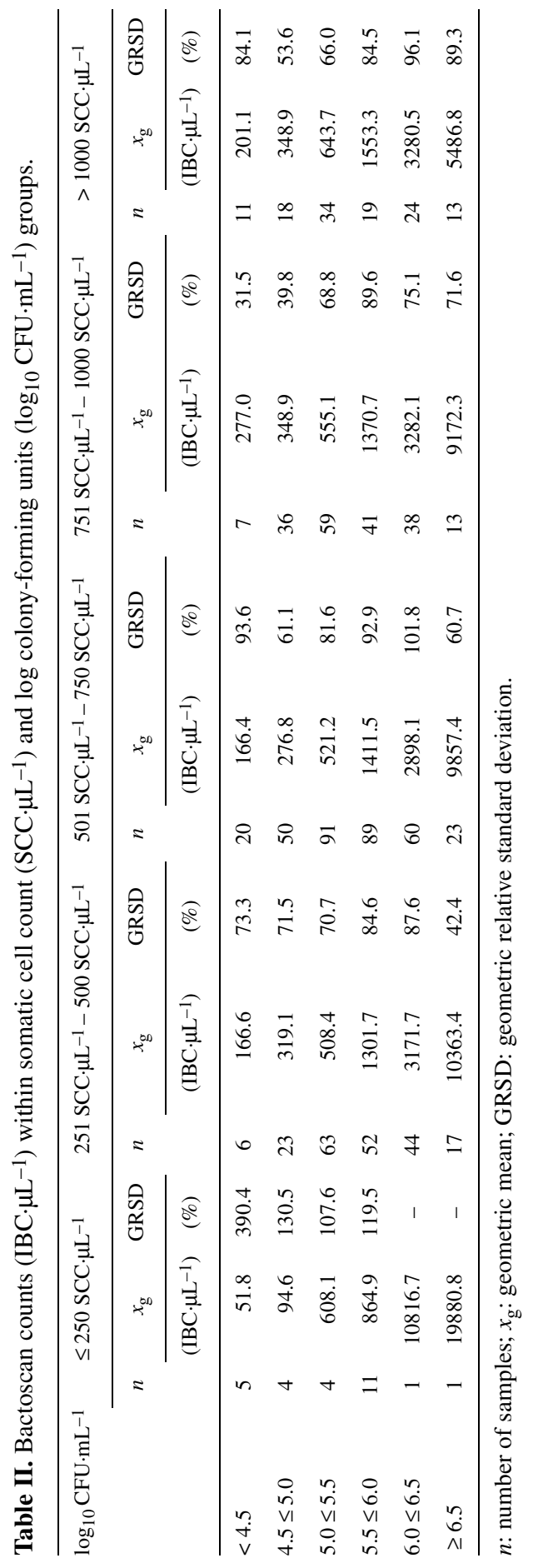


Table III. Bacteriological quality of raw sheep's milk by the anchor method expressed in colonyforming units $\left(\mathrm{CFU} \cdot \mathrm{mL}^{-1}\right)$ [6].

\begin{tabular}{lc}
\hline Number of samples & 913 \\
Geometric mean $\left(10^{3} \mathrm{CFU} \cdot \mathrm{mL}^{-1}\right)$ & 358 \\
Geometric relative standard deviation $(\%)$ & 386.5 \\
Maximum $\left(10^{3} \mathrm{CFU} \cdot \mathrm{mL}^{-1}\right)$ & 231000 \\
Minimum $\left(\mathrm{CFU} \cdot \mathrm{mL}^{-1}\right)$ & 1700 \\
$\leq 500000 \mathrm{CFU} \cdot \mathrm{mL}^{-1}(\%)$ & 58.9 \\
$\leq 1500000 \mathrm{CFU} \cdot \mathrm{mL}^{-1}(\%)$ & 81.4 \\
\hline
\end{tabular}

Table IV. Count of somatic cells (SCC) in raw sheep's milk.

\begin{tabular}{lc}
\hline Number of samples & 877 \\
Geometric mean $\left(\mathrm{SCC} \cdot \mu \mathrm{L}^{-1}\right)$ & 636 \\
Geometric relative standard deviation $(\%)$ & 61.8 \\
Maximum $\left(\mathrm{SCC} \cdot \mu \mathrm{L}^{-1}\right)$ & 7276 \\
Minimum $\left(\mathrm{SCC} \cdot \mu \mathrm{L}^{-1}\right)$ & 40 \\
$\leq 250 \mathrm{SCC} \cdot \mu \mathrm{L}^{-1}(\%)$ & 3.0 \\
$251 \mathrm{SCC} \cdot \mu \mathrm{L}^{-1}-500 \mathrm{SCC} \cdot \mu \mathrm{L}^{-1}(\%)$ & 23.4 \\
$501 \mathrm{SCC} \cdot \mu \mathrm{L}^{-1}-750 \mathrm{SCC} \cdot \mu \mathrm{L}^{-1}(\%)$ & 38.0 \\
$751 \mathrm{SCC} \cdot \mu \mathrm{L}^{-1}-1000 \mathrm{SCC} \cdot \mu \mathrm{L}^{-1}(\%)$ & 22.1 \\
$>1000 \mathrm{SCC} \cdot \mu \mathrm{L}^{-1}(\%)$ & 13.6 \\
\hline
\end{tabular}

IBC counted in raw sheep's milk by BSCFC were also recalculated into CFU. $\mathrm{mL}^{-1}$ using the regression, which was valid for raw cow's milk here [22]:

$\log _{10} \mathrm{CFU} \cdot \mathrm{mL}^{-1}=0.914 \log _{10} \mathrm{IBC} \cdot \mu \mathrm{L}^{-1}+$ 2.842. Transformed results were compared with results obtained through the anchor method [6]. A summary of the differences found between converted and directly measured values (in $\log _{10} \mathrm{CFU} \cdot \mathrm{mL}^{-1}$ ) related to the kind of milk is provided in Table V.

\subsubsection{Comparison of various} conversions on a model data set

Selected conversions both for raw sheep's milk and for raw cow's milk which were established in different countries [8, 19, 21, $22]$ are presented in Table VI. A model data set $(n=50)$ with values from approximately
$19 \mathrm{IBC} \cdot \mu \mathrm{L}^{-1}$ to $2023 \mathrm{IBC} \cdot \mu \mathrm{L}^{-1}$ was converted into $\mathrm{CFU} \cdot \mathrm{mL}^{-1}$ by putting the individual values into each of the equations. The data fulfilled the criteria for normal distribution after logarithmic transformation (the values of obliqueness - 0.006 and acuteness -2.612 were calculated together with inspection of the graphical rendering). The geometrical mean of BSC-FC counts in the set was $192 \mathrm{IBC} \cdot \mu \mathrm{L}^{-1}$. After conversion by different equations, the following geometrical means were obtained, in order from "Slovakia I, 2004, sheep" to "Germany, 1999, cow" (according to Tab. VI): $59000 \mathrm{CFU} \cdot \mathrm{mL}^{-1}, \quad 60000 \mathrm{CFU} \cdot \mathrm{mL}^{-1}$, 13000 CFU.mL-1, 88000 CFU.mL ${ }^{-1}$, $85000 \mathrm{CFU} \cdot \mathrm{mL}^{-1}$ and $75000 \mathrm{CFU} \cdot \mathrm{mL}^{-1}$. Evaluation of the significance of the pair result differences (in $\log _{10} \mathrm{CFU} \cdot \mathrm{mL}^{-1}$ ) within all the combination of the equation results is summarised in Table VII. 
Table V. Verification of regression for raw cow's milk $\left(\log _{10} \mathrm{CFU} \cdot \mathrm{mL}^{-1}=0.914 \log _{10} \mathrm{IBC} \cdot \mu \mathrm{L}^{-1}+\right.$ 2.842) with raw cow's milk samples and raw sheep's milk samples.

\begin{tabular}{ccccccc}
\hline Milk & $n$ & $R_{\mathrm{x}, \mathrm{y}}$ & $\mathrm{d}$ & $\mathrm{s}$ & $\mathrm{d}$ max & $\mathrm{d} \min$ \\
\cline { 4 - 6 } & & & \multicolumn{5}{c}{$\left(\log _{10} \mathrm{CFU} \cdot \mathrm{mL}^{-1}\right)$} \\
\hline Cow & 525 & 0.932 & 0.012 & 0.144 & 0.599 & -0.573 \\
Sheep & 913 & 0.885 & 0.030 & 0.341 & 1.297 & -1.686 \\
\hline
\end{tabular}

$n$ : number of samples; $R_{\mathrm{x} y}$ : correlation coefficient between predicted and measured values; đ: mean of differences; $\mathrm{s}_{\mathrm{d}}$ : standard deviation of differences; $\mathrm{d}$ max: maximal difference; $\mathrm{d}$ min: minimal difference - the values were calculated as predicted values from regression minus measured values by the anchor method [6].

Table VI. Summarisation of various conversions for Bactoscan FC [8, 19, 21, 22].

\begin{tabular}{|c|c|c|c|c|c|}
\hline Study & Milk & $n$ & Conversion & $\begin{array}{c}\mathrm{s}_{\mathrm{y}, \mathrm{x}} \\
\left(\log _{10} \mathrm{CFU} \cdot \mathrm{mL}^{-1}\right)\end{array}$ & $R_{\mathrm{x}, \mathrm{y}}$ \\
\hline $\begin{array}{l}\text { Slovakia I, } \\
2004\end{array}$ & Sheep & 237 & $\log _{10} \mathrm{CFU} \cdot \mathrm{mL}^{-1}=1.125 \log _{10} \mathrm{IBC} \cdot \mu \mathrm{L}^{-1}+2.201$ & 0.310 & 0.867 \\
\hline $\begin{array}{l}\text { Slovakia II, } \\
2004\end{array}$ & Sheep & 877 & $\log _{10} \mathrm{CFU} \cdot \mathrm{mL}^{-1}=1.088 \log _{10} \mathrm{IBC} \cdot \mu \mathrm{L}^{-1}+2.292$ & 0.305 & 0.867 \\
\hline $\begin{array}{l}\text { France, } \\
1998\end{array}$ & Sheep & 534 & $\log _{10} \mathrm{CFU} \cdot \mathrm{mL}^{-1}=1.311 \log _{10} \mathrm{IBC} \cdot \mathrm{mL}^{-1}-2.825$ & 0.350 & - \\
\hline $\begin{array}{l}\text { Slovakia, } \\
2003\end{array}$ & Cow & 1281 & $\log _{10} \mathrm{CFU} \cdot \mathrm{mL}^{-1}=0.935 \log _{10} \mathrm{IBC} \cdot \mu \mathrm{L}^{-1}+2.812$ & 0.250 & 0.886 \\
\hline $\begin{array}{l}\text { Slovakia, } \\
2004\end{array}$ & Cow & 1281 & $\log _{10} \mathrm{CFU} \cdot \mathrm{mL}^{-1}=0.914 \log _{10} \mathrm{IBC} \cdot \mu \mathrm{L}^{-1}+2.842$ & 0.210 & 0.889 \\
\hline $\begin{array}{l}\text { Germany, } \\
1999\end{array}$ & Cow & 1039 & $\log _{10} \mathrm{CFU} \cdot \mathrm{mL}^{-1}=0.923 \log _{10} \mathrm{IBC} \cdot \mu \mathrm{L}^{-1}+2.767$ & 0.302 & 0.710 \\
\hline
\end{tabular}

$n$ : number of samples; $\mathrm{s}_{\mathrm{y}, \mathrm{x}}:$ standard deviation of regression; $R_{\mathrm{x}, \mathrm{y}}$ : correlation coefficient.

\section{DISCUSSION}

\subsection{Method describing criteria}

Upon routine testing it was confirmed that within-laboratory reproducibility of BSC-FC depends on IBC counts [4, 11, 17], no matter which milk was analysed (Tab. I). The obtained $s_{R 1}$ was somewhat better for raw cow's milk than for raw sheep's milk. Still, it was in the same order of magnitude as $s_{r}$ or $s_{R}$ presented in other studies $[4,11$, 17] and it was within desired limits [14]. The only exception was the interval between $10 \mathrm{IBC} \cdot \mu \mathrm{L}^{-1}$ and $50 \mathrm{IBC} \cdot \mu \mathrm{L}^{-1}$ for raw sheep's milk, but only a small data set was appraised here. Precision figures of the anchor method are independent of the counting level and are indicated with repeatability $r=0.25 \log _{10} \mathrm{CFU} \cdot \mathrm{mL}^{-1}$ corresponding to $\mathrm{s}_{\mathrm{r}}=0.089 \log _{10} \mathrm{CFU} \cdot \mathrm{mL}^{-1}$ [6]. Converting the within-laboratory reproducibility data of the $\mathrm{BSC}-\mathrm{FC}$ method by multiplication with the values of the slopes of the regression equations established for sheep's (factor 1.088) and cow's milk (factor 0.914) (Tab. VI) makes it obvious that, with the exception of raw sheep's 


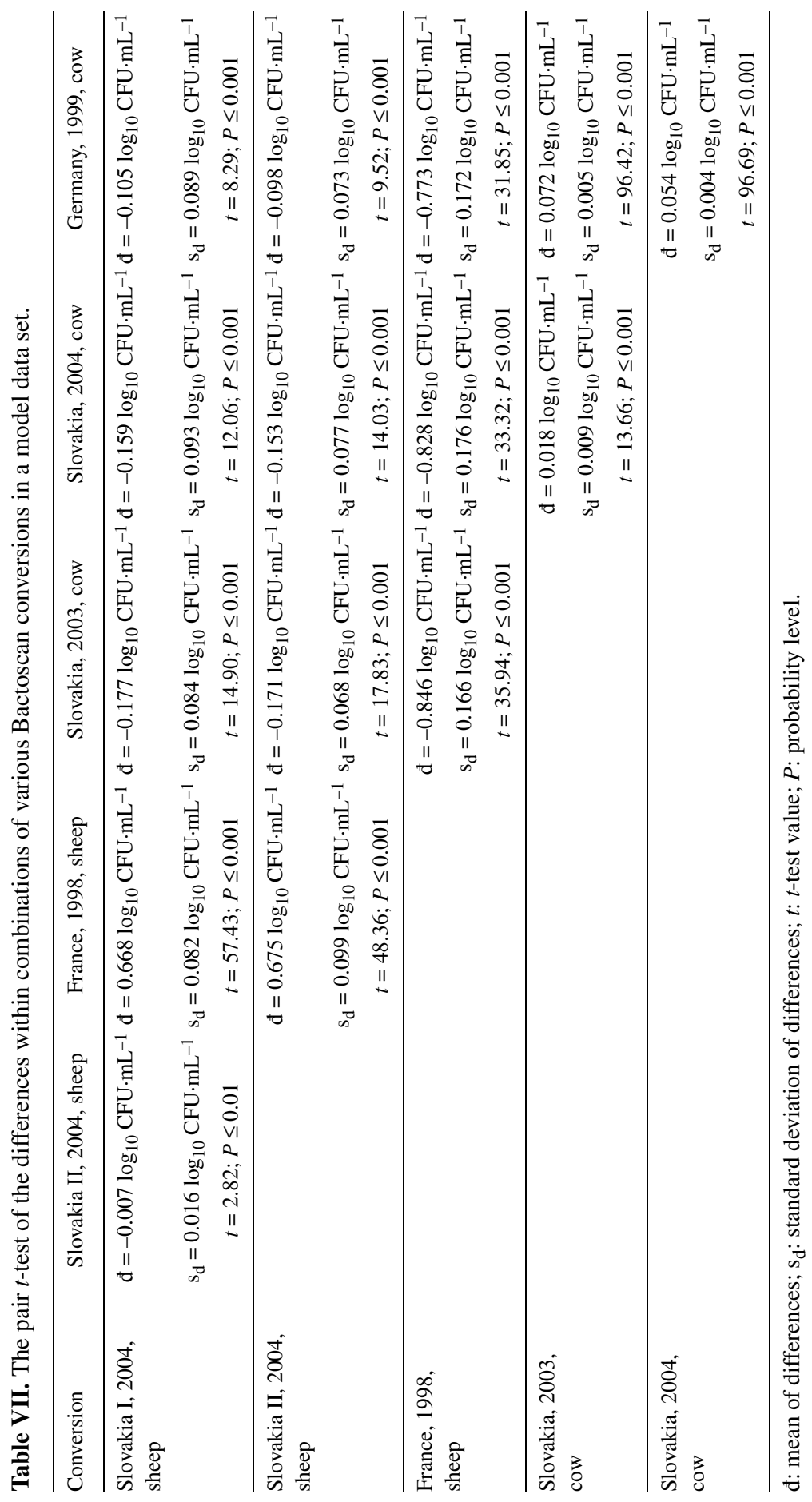


milk in the lowest counting group, the withinlaboratory reproducibility of the BSC-FC method is superior to that of the anchor method. Nevertheless, a preceding raw sheep's milk sample with higher bacterial counts (> $\left.20000 \mathrm{IBC} \cdot \mu \mathrm{L}^{-1}\right)$ often enhanced the first result of next sample, when its count was lower. This was observed in spite of the fact that the carry-over effect in the BSC-FC was always compensated for, although regularly only with raw cow's milk. In such selected sample sets withinlaboratory reproducibility was poorer. In the interval $201 \mathrm{IBC} \cdot \mu \mathrm{L}^{-1}-2000 \mathrm{IBC} \cdot \mu \mathrm{L}^{-1}$ the $\mathrm{s}_{\mathrm{R} 1}$ was $0.108 \log _{10} \mathrm{IBC} \cdot \mu \mathrm{L}^{-1}(n=44)$ and in the interval $2001 \mathrm{IBC} \cdot \mu \mathrm{L}^{-1}$ $20000 \mathrm{IBC} \cdot \mu \mathrm{L}^{-1}$ the $\mathrm{s}_{\mathrm{R} 1}$ was $0.062 \log _{10}$ $\mathrm{IBC} \cdot \mu \mathrm{L}^{-1}(n=32)$. These samples were excluded from the further establishment of the conversion.

Ninane et al. [11] verified the independence of their conversion for SCC at typical levels of somatic cells in raw cow's milk. However, somatic cells are naturally higher in raw sheep's milk there [2] (Tab. IV) and they might, in counts $\geq 1000000 \mathrm{SCC} \cdot \mathrm{mL}^{-1}$, have an effect on the enumeration of bacterial cells by BSC-FC [16]. If there is an influence, it is expected to become visible in samples with high somatic cells and low CFU compared with ones with low somatic cells and low CFU. As can be seen from Table II, such a trend was slightly indicated in intervals $<5.0 \log _{10} \mathrm{CFU} \cdot \mathrm{mL}^{-1}$, but in other groups it was not pronounced. From these orientating trials on the influence of somatic cell content on the counting level of the BSC-FC method it cannot be excluded that in milk with very good bacteriological quality the BSC-FC count might be influenced by elevated SCC.

\subsection{Conversion into $\mathrm{CFU}$}

Samples used for the establishment of the conversion need to cover the spectrum of possible influencing factors on the test results $[10,19]$. The number of bulk samples used in this study and the fact that they were sampled from the majority of sheep's milk producers in Slovakia during the whole production season, from April to September, met the requirements [10] for creating a fully representative data set. Dominant breeds were Cigaja and Valaska sheep, and marginal Lacone and Eastfreesian sheep. Milk was stored in refrigerated farm tanks and was delivered to the dairies every 2 nd day. Each farm was inspected by the dairies at a minimum of twice per month, with the exception of one dairy, which took only one sample per month and per farm. These data are not as exact as for raw cow's milk, since it was concluded not to involve any individual corrections representing these structural factors into the built conversion [19].

Conversion aims to bridge the gap between results obtained with different methods - here SPC and BSC-FC - and expressed in different units. The transformation of results into $\log _{10}$ form and the utilisation of data between percentiles 1 and 99 (877 pairs of measurements) for the calculation of linear regression were a precondition for their further evaluation and comparison with conclusions from raw cow's milk studies [20-22] executed in Slovakia. Results from the anchor $\left(x_{\mathrm{g}}=\right.$ $359000 \mathrm{CFU} \cdot \mathrm{mL}^{-1}$; GRSD $\left.=309.7 \%\right)$ as well as the routine method $\left(x_{\mathrm{g}}=\right.$ 999 IBC $\cdot \mu L^{-1} ;$ GRSD $=207.8 \%$ ) exhibited nearly normal distributions. A distinct deviation was also observed in $\log _{10} \mathrm{CFU} \cdot \mathrm{mL}^{-1}$ data, due to the same reason described in other studies [19,20]. Visual inspection of the scattergram representing the relationship between $\log _{10}$ IBC $\mu \mathrm{L}^{-1}$ and $\log _{10}$ $\mathrm{CFU} \cdot \mathrm{mL}^{-1}: \log _{10} \mathrm{CFU} \cdot \mathrm{mL}^{-1}=1.088 \log _{10}$ IBC $\cdot \mu \mathrm{L}^{-1}+2.292$ showed an almost uniform and good correlation $\left(R_{\mathrm{x}, \mathrm{y}}=0.867\right.$; $T=51.50)$ for the whole measurement range (Fig. 1).

The actual conversion for raw cow's milk in Slovakia was verified both with cow's milk and with sheep's milk (see Sect. 3.2.3). Certain divergences were indicated from the results presented in Table V, where predicted - converted and directly measured results were balanced. While for raw cow's milk samples the mean of differences was not significant $(P>0.05, t=$ $1.86)$, it was significant for sheep's milk at $P \leq 0.01(t=2.70)$ (on the average level $370000 \mathrm{CFU} \cdot \mathrm{mL}^{-1}$ it was $\left.26000 \mathrm{CFU} \cdot \mathrm{mL}^{-1}\right)$. Regardless of the tested milk, the correlations 


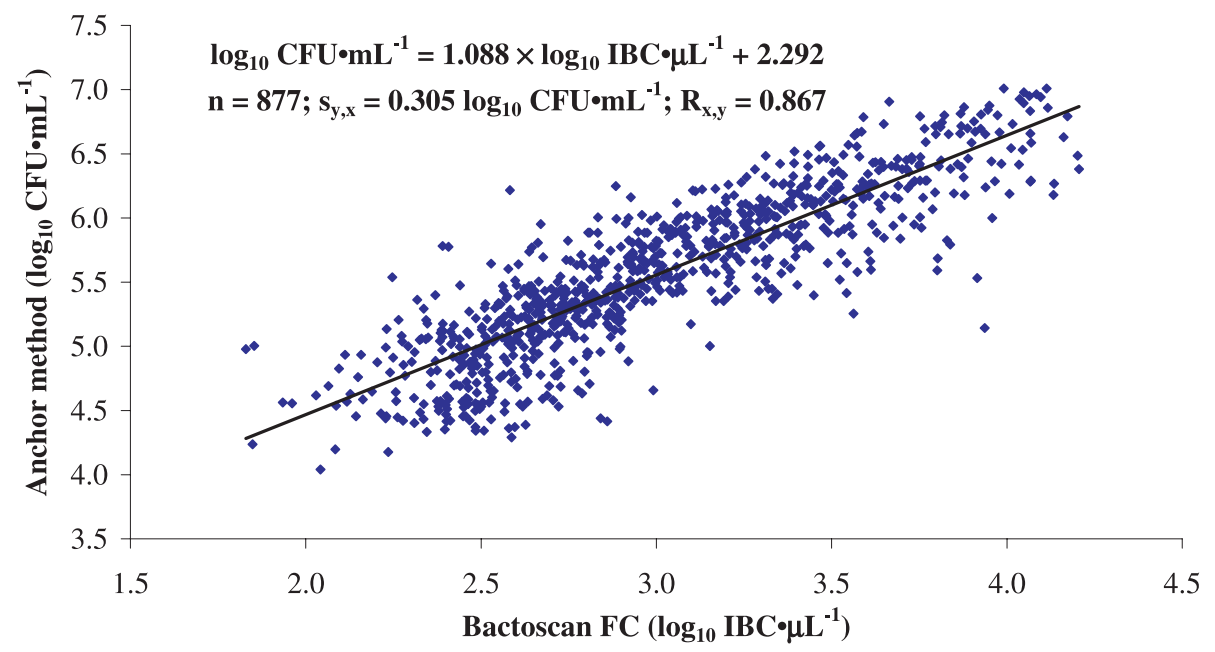

Figure 1. Relation between $\log _{10} \mathrm{IBC} \cdot \mu \mathrm{L}^{-1}(x)$ and $\log _{10} \mathrm{CFU} \cdot \mathrm{mL}^{-1}(y)$ in raw sheep's milk. $n$ : number of samples; $\mathrm{s}_{\mathrm{y}, \mathrm{x}}$ : standard deviation of regression; $R_{\mathrm{x}, \mathrm{y}}$ : correlation coefficient.

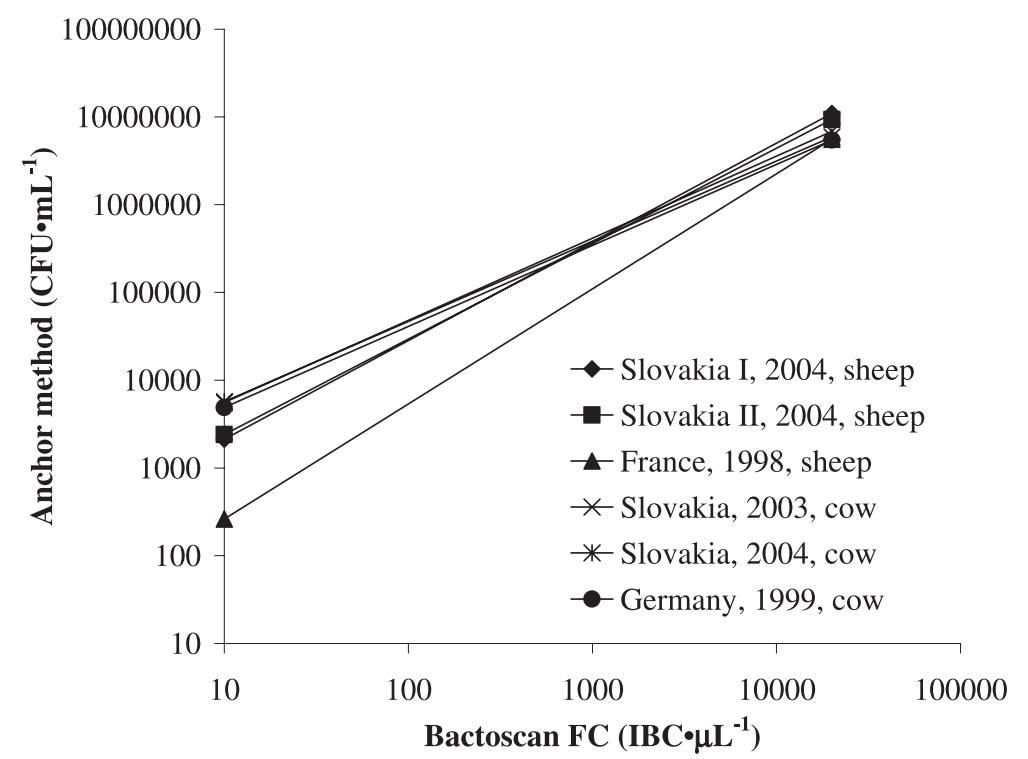

Figure 2. Relation between IBC $\cdot \mu \mathrm{L}^{-1}(x)$ and $\mathrm{CFU} \cdot \mathrm{mL}^{-1}(y)$ by different Bactoscan FC conversions $[8,19,21,22]$.

between both values were good, slightly better for raw cow's milk (raw sheep's milk: $R_{\mathrm{x}, \mathrm{y}}=0.885, T=57.37$; raw cow's milk: $\left.R_{\mathrm{x}, \mathrm{y}}=0.932, T=58.80\right)$.
For demonstration of differences in the conversions (Tab. VI) in the whole measurement range of BSC-FC $\left(10 \mathrm{IBC} \cdot \mu \mathrm{L}^{-1}-\right.$ $\left.20000 \mathrm{IBC} \cdot \mu \mathrm{L}^{-1}\right)$, Figure 2 was created. 
Table VIII. Evaluation of differences between regression coefficients of various Bactoscan conversions.

\begin{tabular}{lccc}
\hline Conversion & $t$ & DF & $P$ \\
\hline $\begin{array}{l}\text { Slovakia, 2004, cow } \\
\text { Germany, 1999, cow }\end{array}$ & 0.312 & 2316 & $>0.05$ \\
$\begin{array}{l}\text { Slovakia, 2003, cow } \\
\text { Slovakia, 2004, cow }\end{array}$ & 1.093 & 2558 & $>0.05$ \\
$\begin{array}{l}\text { Slovakia I, 2004, sheep } \\
\text { Germany, 1999, cow }\end{array}$ & 4.023 & 1272 & $<0.001$ \\
$\begin{array}{l}\text { Slovakia II, 2004, sheep } \\
\text { Slovakia, 2004, cow }\end{array}$ & 7.361 & 2154 & $<0.001$ \\
$\begin{array}{l}\text { Slovakia I, 2004, sheep } \\
\text { Slovakia II, 2004, sheep } \\
\text { Slovakia II, 2004, sheep } \\
\text { Germany, 1999, cow }\end{array}$ & 0.792 & 1110 & $>0.05$ \\
\hline
\end{tabular}

$t: t$-test value; DF: degrees of freedom; $P$ : probability level.

According to [10] it should be checked whether the newly calculated regression coefficients are not significantly different from the one applied so far. Although this requirement is related to the verification procedure, it can also be implemented for comparison between conversions created for various purposes (e.g. for sheep's and cow's milk). Valuation of the parallelism of the presented lines (with the exception of "France, 1998, sheep" in which a difference is obvious) is done in Table VIII. It can be seen that only combinations where sheep's and cow's conversions were compared with each other are statistically significant. On the other hand, the difference between "Slovakia I, 2004, sheep" and "Slovakia II, 2004, sheep" was not considered as significant. The first conversion was calculated at the beginning of the study in the same way as the final one, "Slovakia II, 2004, sheep", only the number of samples was lower $(n=$ 237). It suggests the good time stability of the sheep's conversion during the season. Similarly, it was verified for raw cow's milk conversion here ("Slovakia, 2003, cow" and "Slovakia, 2004, cow") [22].

For further evaluation of various conversions, the model data set was introduced (see Sect. 3.2.4). The minimal value after conversion was equal to $10000 \mathrm{CFU} \cdot \mathrm{mL}^{-1}$, the maximal value $800000 \mathrm{CFU} \cdot \mathrm{mL}^{-1}$. The mentioned variation range of SPC was selected in the framework of real practical possibilities for both kinds of milk. From Table VII it is evident that all calculated differences were statistically significant $(P \leq 0.01$ and $P \leq 0.001)$. The lowest significance was at the difference within the combination "Slovakia I, 2004, sheep" and "Slovakia II, 2004, sheep". A small difference (đ and $s_{d}$ ) was also observed between "Slovakia, 2003, cow" and "Slovakia, 2004, cow" but during evaluation it was considered as significant at $P \leq 0.001$. The "France, 1998, sheep" equation differed the most from the other, with respect to đ and $\mathrm{s}_{\mathrm{d}}$. To evaluate the attained out test results, it is necessary to stress that they are obviously valid just for a selected variation range of bacteria counts in the model data set.

Established conversions are characterised by $\mathrm{s}_{\mathrm{y}, \mathrm{x}}$. In the French study [8], a higher value of $\mathrm{s}_{\mathrm{y}, \mathrm{x}}$ for raw sheep's milk $\left(0.350 \log _{10}\right.$ $\left.\mathrm{CFU} \cdot \mathrm{mL}^{-1}-0.385 \log _{10} \mathrm{CFU} \cdot \mathrm{mL}^{-1}\right)$ was obtained than for raw cow's milk $\left(0.320 \log _{10}\right.$ $\left.\mathrm{CFU} \cdot \mathrm{mL}^{-1}\right)$. A similar trend was also observed here (Tab. VI). The derived accuracy of the method $\left( \pm 1.96 \times s_{y, x}\right)$ [9] is 
Table IX. Estimation of the accuracy of the regression for raw sheep's milk.

\begin{tabular}{llr}
\hline Level & \multicolumn{2}{c}{$\begin{array}{c}\text { Confidence interval* } \\
\left(10^{3} \mathrm{CFU} \cdot \mathrm{mL}^{-1}\right)\end{array}$} \\
\hline 500 & 126 & 1980 \\
1500 & 379 & 5941 \\
\hline
\end{tabular}

* The accuracy calculated as $\pm 1.96 \times \mathrm{s}_{\mathrm{y}, \mathrm{x}}$; where $\mathrm{s}_{\mathrm{y}, \mathrm{x}}=0.305 \log _{10} \mathrm{CFU} \cdot \mathrm{mL}^{-1}$

demonstrated in Table IX, in which existing limits for raw sheep's milk [13] were taken into consideration.

\section{CONCLUSION}

Quality assessment of collected milk is obligatory for dairies [13]. Introduction of rapid methods is beneficial for farmers too, as they can be informed about quality quickly and they can make necessary corrections. However, they must be as reliable as possible. Bactoscan ${ }^{\circledR}$ FC was approved as an alternative microbiological method for the examination of raw cow's milk in many countries including Slovakia. To evaluate it for raw sheep's milk testing the experiments described above were performed.

The achieved within-laboratory reproducibility of BSC-FC is rated to be excellent in comparison with the anchor method [6], except for a low counting level $\leq 50 \mathrm{IBC} \cdot \mu \mathrm{L}^{-1}$ and situations when a preceding sample exhibited higher bacterial counts $\left(>20000 \mathrm{IBC} \cdot \mu \mathrm{L}^{-1}\right)$. In routine procedure, repeated testing of such samples is therefore advised for carryover avoidance. Counts of bacteria in raw sheep's milk are generally higher than in raw cow's milk. The results of bacteriological quality were distributed through the whole measuring range of BSC-FC. Thus bulk samples with low SPC and high SCC, in which the possible effect of somatic cells on counting by BSC-FC can be more noticeable, are expected only rarely.

Conclusions drawn from the establishment of conversion of BSC-FC counts into the anchor SPC method units [6] for raw sheep's milk, estimation of the accuracy of the conversion, and the verification studies performed support the requirements of ISO 21187 [10]. It means to create the conversion with respect to conditions of its future use. It was confirmed that the kind of milk in terms of species is an important variable. The differences achieved could be explained by the mutual combinations of not only different kinds of milk and local specific influences on the bacteriological spectrum of milk contaminations, but also by the laboratory impact on the anchor method's performance and by individual instrumental effects. As the created relationship between the results of the methods is linked with the multi-variable system, it is advised to verify it permanently.

Acknowledgements: The study was granted by the State research and development programme of the Slovak Republic "Food - quality and safety", 2003SP270280E010280E01 and by the Ministry of Agriculture of the Czech Republic MZe-CR, NAZV, QF 3019. The authors are grateful to all employees of the dairies who were responsible for sampling, and to the analysts of TL Examinala and TL Milex-Progres for performing of tests. Also, we would like to thank Dr. G. Wyatt from IFR Norwich and Mgr. K. Albrechtová for improving the English and the French translation.

\section{REFERENCES}

[1] Anifantakis E.M., Comparison of the physico-chemical properties of ewe and cow milks, Bull. Int. Dairy Fed. 202 (1986) 42-53.

[2] Baro J.A., Carriedo J.A., San Primitivo F., Genetic parameters of test day measures for somatic cell count, milk yield, and protein percentage of milking ewes, J. Dairy Sci. 77 (1994) 2658-2662.

[3] Bolzoni G., Marcolini A., Varisco G., Evaluation of the Bactoscan FC. 1. Accuracy, comparison with Bactoscan 8000 and somatic cells effect, Milchwissenschaft 55 (2000) 67-80.

[4] Bolzoni G., Marcolini A., Varisco G., Evaluation of the Bactoscan FC. 2. Stability, repeability, carry-over and linearity, Milchwissenschaft 56 (2001) 318-321.

[5] European Committee for Standardization, General requirements for the competence of testing 
and calibration laboratories, EN ISO/IEC 17025, Brussels, Belgium, 1999.

[6] European Committee for Standardization, Microbiology of food and animal feeding stuffs - Horizontal method for the enumeration of microorganisms - Colony-count technique at $30{ }^{\circ} \mathrm{C}$, EN ISO 4833 , Brussels, Belgium, 2003.

[7] European Committee for Standardization, Microbiology of food and animal feeding stuffs - Protocol for the validation of alternative methods, EN ISO 16140, Brussels, Belgium, 2003.

[8] Foss Electric, Test of Bactoscan FC on sheep's milk at LIAL Aurillac, France Autumn 1998, Hillerød, February 1999.

[9] International Standard Organization, Milk Definition and evaluation of the overall accuracy of indirect methods of milk analysis Part 2: Calibration and quality control in the dairy laboratory, ISO 8196-2, Geneva, Switzerland, 2000.

[10] International Standard Organization, Milk Quantitative determination of bacteriological quality - Guidance for establishing and verifying a conversion relationship between routine method results and anchor method results, ISO 21187, Geneva, Switzerland, 2004.

[11] Ninane V., De Reu K., Oger R., Reybroeck W., Guyot A., Évaluation du Bactoscan FC pour la numération des bactéries du lait cru, Lait 80 (2000) 527-538.

[12] Rapp M., Münch S., Neuentwicklung von flüssigen Konservierungsmitteln für Milchproben, Dtsch. Molk. Zeit. 105 (1984) 1264 1272.

[13] Regulation (EC) No 853/2004 of the European Parliament and of the Council of 29 April 2004 laying down specific hygiene rules for on the hygiene of foodstuffs, Official Journal of the European Union L 139/55, 30.4.2004.
[14] Slovak Institute for Standardization, Automatic determination of microorganisms in raw milk by direct enumeration of bacterial cells, STN 57 0539, Bratislava, Slovakia, 2003.

[15] Suhren G., Reichmuth J., Interpretation of quantitative microbiological results, Milchwissenschaft 55 (2000) 18-22.

[16] Suhren G., Walte H.-G., First experiences with automatic flow cytometric determination of total bacterial count in raw milk, Kiel. Milchwirtsch. Forschungber. 50 (1998) 249275.

[17] Suhren G., Walte H.-G., Determination of precision data of the Bactoscan FC-method by an interlaboratory study, Kiel. Milchwirtsch. Forschungsber. 53 (2001) 269-282.

[18] Suhren G., Walte H.-G., Reichmuth J., Zum Einsatz der automatisierten Durchflusszytometrie als Routinemethode für die Erfassung der bakteriologischen Qualität von Anlieferngsmilch, Kiel, Milchwirtsch. Forschungsber. 52 (2000) 97-143.

[19] Suhren G., Reichmuth J., Walte H.-G., Bacteriological quality of raw milk: Conversion of Bactoscan-FC counts onto the scale of the official method, Milchwissenschaft 56 (2001) 380-384.

[20] Tomáška M., Suhren G., Experiences with introduction of the Bactoscan FC in Slovakia, Bull. Int. Dairy Fed. 383 (2003) 58-60.

[21] Tomáška M., Suhren G., Verification Study on Bactoscan FC counts conversion onto the scale of the reference method, Milchwissenschaft 59 (2004) 261-262.

[22] Tomáška M., Hofericová M., Slottová A., Bactoscan FCTM - alternatívna metóda merania mikrobiologickej kvality surového mlieka, in: Burdová O., Baranová M. (Eds.), Proceedings from Hygiena Alimentorum XXV, 27th - 28th May 2004, Strbské Pleso - Vysoké Tatry, University of Veterinarian Medicine, Košice, Slovakia, 2004, pp. 62-65. 